\title{
LEADERSHIP AND CORPORATE SOCIAL RESPONSIBILITY
}

\author{
Hortensia GORSKI \\ Romanian-German University, Sibiu, Romania \\ hortensia.gorski@roger-univ.ro
}

\begin{abstract}
Leadership and Corporate Social Responsibility (CSR) are some of the most widely studied topics, generating an extensive literature. Nowadays, leaders are facing economic, social and environmental challenges. Unfortunately, today trust in business is low. In this complex global environment of uncertainty and ambiguity, leaders have to anticipate the changes and to be catalysts for shifting their organizations towards a sustainable society. The purpose of the present paper is to investigate leaders' opinion regarding: Corporate responsibilities (Carroll's' four-layered pyramid model); Reasons for CSR actions/ projects; Areas of interest for CSR projects/ activities/ initiatives. Taking into account the growing interest towards a sustainable society is a need for a new type of leadership that promotes the CSR's ideals.
\end{abstract}

\section{Keywords: Corporate Social Responsibility (CSR), leadership, business ethics}

\section{Introduction}

Nowadays, organizations are facing economic, social and environmental challenges: globalization, economic recession, population growth (overpopulation), exploitation of natural resources, extreme poverty (rich-poor gap), unprecedented inequality, global migration, religious extremism and terrorism, geopolitical and ecological crises, global warming and its effect on climate change, environmental issues, competitive pressure, health issues, new information and communication technologies, sustainable lifestyle and so on. In this context, taking into account all these complex challenges, sustainable development and social responsibility are very "hot" topics. In the age of sustainable development, there is a need for "a holistic framework, in which society aims for economic, social, and environmental goals" [1]. The challenge for the companies is to incorporate ethical, social and environmental values in their business practice.
"A firm takes on a visible role in the society which goes beyond the core business and beyond what the law requires and which leads to added value for the company and the society" [2].

Leadership and Corporate Social Responsibility (CSR) are some of the most widely studied topics, generating an extensive literature. This paper discusses the important role of leadership in implementing CSR practices, taking into account the growing interest towards business ethics. Nowadays, leaders are facing economic, social and environmental challenges. Rapid pace of change is forcing leaders to find creative and innovative solutions to cope with multiple stakeholders, whose interests, needs and requirements could sometimes be in conflict. Unfortunately, today's trust in business is low. In this complex global environment of uncertainty and ambiguity, leaders should anticipate the changes and act as catalysts for shifting their organizations towards a sustainable society. 
Taking into account not only the economic, but also the environmental and social challenges of the $21^{\text {st }}$ century, a new type of leadership that promotes the CSR's ideals is needed.

\section{Some Corporate Social Responsibility (CSR) trends}

Corporate Social Responsibility has become "one of the (new) organizational challenges over the past decade, certainly when viewed from the perspective of the growing needs and obligations for sustainability" [3]. Although there is a rich literature on CSR and there are many available definitions, the concept is still difficult. There is a lot of confusion because, both in theory and practice, there are a lot of different terms which overlap with, are connected or synonymous with CSR, such as "corporate citizenship, sustainable business, environmental responsibility, the triple bottom line; social and environmental accountability; business ethics and corporate accountability" [4]. Different perceptions of CSR have generated a series of misunderstandings and have created for organizations barriers in the way of approaching CSR opportunities and challenges. Different authors and numerous international organizations, including in particular the European Union, have examined and classified the concept and theories of corporate social responsibility (CSR), and have interpreted it in different ways [5], [6].

Alexander Dahlsrud underlined that "Despite numerous efforts to bring about a clear and unbiased definition of CSR, there is still some confusion as to how CSR should be defined" [7]. In order to study the similarities and differences between the available definitions, Dahlsrud analysis the content of 37 definitions of CSR and identified five dimensions: the stakeholder dimension, the social dimension, the economic dimension, the voluntariness dimension, the environmental dimension.

Carroll has proposed and developed, one of the most elaborate, complete and most widely accepted CSR model [8], [9] further employed by many researchers. In the fourlayered pyramid model, corporate social responsibility has been described as a multilayer concept with different responsibilities: economic (to gain profits); legal (to obey law), ethical (to act rightly, justly, honestly) and philanthropic (to be a good citizen). Chandler and Werther also emphasize the importance of addressing different arguments for CSR - "ethical, moral, national, and economic" [10]. "A business needs a successful community, not only to create demand for its products but also to provide public assets and a supportive environment. A community needs successful business to provide jobs and wealth creation opportunities for its citizens"[11].

Businesses are the engine of society. Philip Kotler and Nancy Lee focus their CSR definition on voluntary business commitment and on the importance of doing good. They consider that "corporate social responsibility is a commitment to improve community well-being, through discretionary business practices and contributions on corporate resources" [12].

\section{Leadership and CSR}

The $21^{\text {st }}$ century world is shaped by leaders. Keith Grint considers that "Leadership, or the lack of it, seems to be responsible for just about everything these days" [13]. Leadership is a very complex concept. Over time, many definitions have been developed and there is no consensus on a universally agreed definition. There are "almost as many definitions of leadership as there are persons who attempted to define the concept" [14].

In order to build a sustainable world, intersection of leadership and ethics is a must. Leadership has a vital role in promoting an ethical and moral behaviour. Moreover, leaders should be models for the followers and should aim to shape organizations by their own values and characteristics. Employees rely on their leaders for guidance when faced with ethical dilemmas [15]. Leaders' behaviour should 
be "visible and consistently ethical, both internally and externally to the organization" [16]. Moreover, "excellent companies do more than talk ethics, they take positive steps to address ethical issues and apply the practical tools of ethics in their management practice" [17]. Ethics has "a central role in the practice of leadership" [18]. Nowadays, there is a higher need for ethical leaders and transparency in business processes.

The role of Corporate Social Responsibility (CSR) is "to restore one of the most critical resources for businesses' sustainability: trust." Companies choose to incorporate CSR into their businesses for different reasons. It is important to "distinguish between activities for gaining popularity and those which gain trust" [19]. Trust, ethics, CSR and leadership are interlinked. Nowadays, "too often, executives have viewed corporate social responsibility (CSR) as just another source of pressure or passing fad" [20]. Corporate Social responsibility is an ethical framework. Leaders and organizations engaged in CSR act for the benefit of their stakeholders employees, customers, suppliers, community and society at large. CSR requires the use of non-coercive influence and "soft power" which again are specific to leadership [21]. Leaders have a crucially significant role in adopting and practicing CSR in their organizations [22].

\section{Research methodology}

This paper is part of a more comprehensive study regarding leadership, ethics and CSR.

\subsection{Scope, sample, data collection and data analysis}

The purpose of the present paper is to investigate leaders' opinion regarding CSR practices/ activities.

In order to validate the initial hypothesis, a research based on a questionnaire has been conducted in 2016, taking into consideration the population of private companies (microenterprise, SMEs, and large enterprises) from various sectors in Sibiu County. Most of the questionnaire's items were presented using a five-point Likert scale. The survey was unconcealed, the aim being known from the beginning by the respondents - senior and middle managers with significant influence on their companies' operation. For the purpose of this study the disproportionate variant and an availability sample (the sample subjects do not correspond to their statistical reality in terms of percentage in total employers from Sibiu County) have been used. Using an availability sample, the survey has given more importance to large, medium and small firms, than to the group of microenterprises (without eliminating these).

Before administration, the questionnaire was tested on a panel of 8 managers/ leaders (representatives of micro, small, medium and large enterprises). Data were processed, analysed and presented using IBM SPSS Statistics 19 for Windows package program and Microsoft Excel 2010.

\subsection{Findings and research's results}

- Companies' responsibilities

The Carroll's multi-layer CSR pyramid, was employed in this study. Each of these four categories was ranked on a Likert scale (From 1 - No importance to 5 - Very important).

$\Rightarrow$ Economic responsibilities (being profitable; maintaining high level of efficiency; producing good quality products/ services; creating assets);

$\Rightarrow$ Legal responsibilities (not breaking the laws; obeying the laws; behaving in the spirit and letter of law);

$\Rightarrow$ Ethical (Business ethics; Personal ethical awareness);

$\Rightarrow$ Philanthropic responsibilities (contribution to the internal and external community for improving the quality of life; material, financial and human resource contribution - charity and volunteering).

As we can remark in figure 1, economic responsibilities were evaluated as being most important (4.57), followed by the legal responsibilities (4.21) and ethical responsibilities (3.94). The philanthropic responsibilities were perceived by managers as last important to business (3.44). 


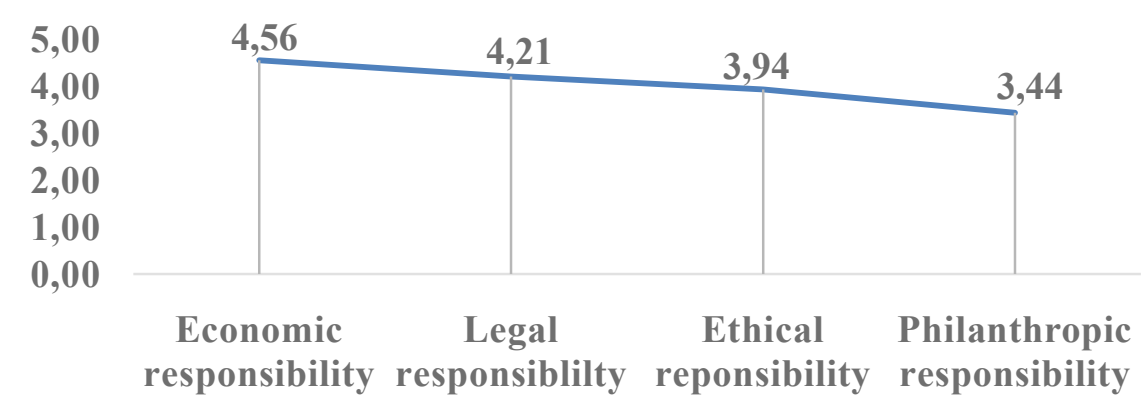

Figure 1: Type of responsibilities

- Reasons for CSR actions/ projects

The most important reasons for managers' engagement in CSR actions/ projects are: the legal pressure (4.16) and the interest in attracting and maintaining talents (4.02) figure 2. Investigated leaders consider that CSR practices are generating a neutral to important influence on companies' visibility \& image improvement (3.35). In the respondents opinion, the market (customers, suppliers) exert only a small to neutral pressure (2.79) for implementing CSR practices. Another revealed aspect is that ONGs and the community also exert only a small to neutral pressure (2.46 respectively
2.57) for CSR investments. Although many respondents consider that companies should have ethical responsibilities to their employees, customers and society as a whole, they sustain that nowadays business ethics arguments have only a small to neutral influence on companies' behavior (2.92). In the current research, the economic reasons for investing in CSR are ranked on the last place. Respondents consider that CSR practice generate only a small influence (2.45) on the company's economics (profit, return of investment, assets).

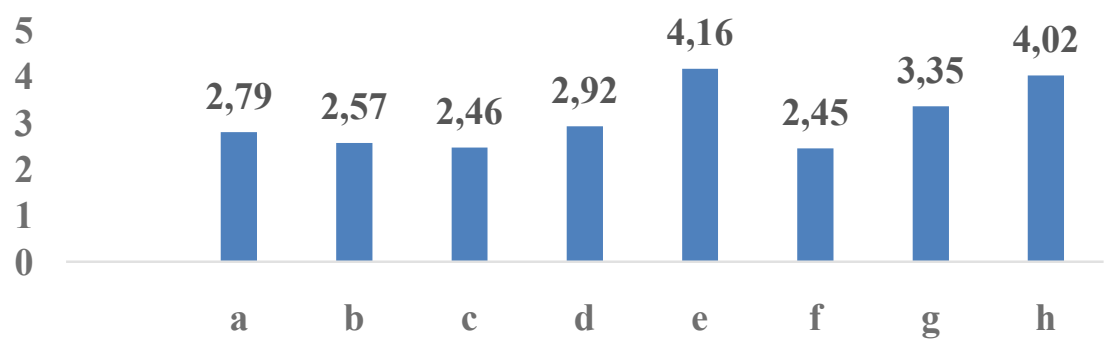

Figure 2: Reasons for CSR practices

a - Market pressure (clients, suppliers);

$\mathrm{b}$ - Community pressure;

c - ONG pressure;

$\mathrm{d}$ - Business ethics arguments;

e - Legal pressure;

$\mathrm{f}$ - Economic reasons;

$\mathrm{g}$ - Image improvement (visibility);

$\mathrm{h}$ - Attract and retain the best employees (talents)
- Areas of interest for CSR projects/ activities/initiatives

Regarding the four areas or pillars of CSR, we can observe (figure 3 ) that Workplace is considered as being the most important (4.16), followed by Marketplace (4.12) and Environment (3.58). Community engagement received the smallest interest (3.05) and is not associated enough with core business concerns. 


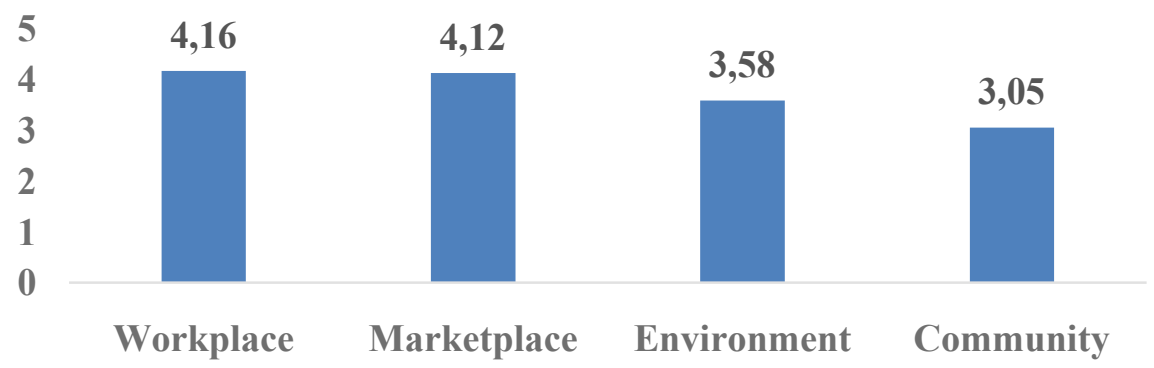

\section{Conclusions}

The presented results should be linked with the other findings of the study regarding leadership, ethics and CSR.

Fortunately, investigated leaders understood the importance of providing employees with a safe, fair and inclusive workplace, in order to attract and maintain talents (the best employees). Respondents are aware of the companies' economics and legal responsibilities, but place philanthropic companies on the last place. Companies may shirk philanthropic issues because it may not seem as important. Investigated leaders take into consideration workplace, marketplace, and even environmental issues, but community engagement is not considered relevant enough for their business. Unfortunately, leaders don't perceive at the right value the wide range of benefits generated by working with their local community. In the age of responsibility, leaders should understand that companies are being part of the society and social issues have an important relevance for their business. Leaders should both volunteer and encourage employees to volunteer for community and make charitable donations. Ethical issues, and community engagement should be more associated with long term business success.

Taking into account the growing interest for a sustainable society, a new type of leadership that promotes the CSR's ideals is needed.

\section{References}

[1] Sachs J. D., The Age of Sustainable Development, Columbia University Press, 2015, p. 3 .

[2] Graafland, J.J., Eijffinger, S.C.W. and Smid, H., Benchmarking of Corporate Social Responsibility (CSR): Methodological Problems and Robustness, Journal of Business Ethics, Vol. 53, No. 1-2, pp. 137-152, 2004. MPRA Paper No. 20771, posted 18. February 2010 17:28 UTC, pp.1-16., online at http://mpra.ub.uni-muenchen.de/20771/.

[3] Jonker J., de Witte M., Finally in Business: Organising Corporate Social Responsibility in Five, in Jonker, Jan, Witte, Marco de (Eds.), Management Models for Corporate Social Responsibility, pp. 1-7, Berlin Heidelberg Springer-Verlag, 2006, p. 2.

[4] Moon J., Government as a Driver of Corporate Social Responsibility, in Dirk Matten (Editor), International Centre for Corporate Social Responsibility, No. 20-2004 ICCSR Research Paper Series, 2004, p. 2.

[5] Gorski, H., Fuciu, M., Croitor, N., Research on Corporate Social Responsibility in the Development Region Centre in Romania, Procedia Economics and Finance, 16, pp. 224 $-233,2014$.

[6] Gorski, H., Fuciu, M., and Dumitrescu, L., Corporate Social Responsibility and Marketing Communication, Revista Economică, Vol. 68, No. 2, pp. 86-106, 2016.

[7] Dahlsrud, A., How corporate social responsibility is defined: an analysis of 37 definitions in Corporate Social Responsibility and Environmental Management, Vol 15, No. 1, pp. 1-13. DOI: 10.1002/csr.132, 2006. 
[8] Carroll A.B., The pyramid of corporate social responsibility: Toward the moral management of organizational stakeholders, Business Horizons, Vol. 34, No. 4, pp. 3948, 1991.

[9] Carroll, A.B., A Three-Dimensional Conceptual Model of Corporate Performance, Academy of Management Review, Vol. 4, No. 4, pp. 497-505, 1997.

[10] Chandler D., and Werther W. B., Strategic Corporate Social Responsibility: Stakeholders, Globalization, and Sustainable Value Creation (3rd Edition), SAGE Publications, Inc, 2013, pp. 21-30.

[11] Porter, M. E. and Kramer, M. R., Creating Shared Value. How to reinvent capitalismand unleash a wave of innovation and growth, Harvard Business Review, (January/February), pp. 63-70, 2011.

[12] Kotler Ph., and Lee N., Corporate Social Responsibility: Doing the Most Good for Your Company and Your Cause (1 edition), Wiley, 2004, pp. 50-51.

[13] Grint K., Leadership: Limits and Possibilities (Management, Work and Organisations), Palgrave Macmillan 2005, p. 5.

[14] Stogdill, R.M., Handbook of Leadership: A Survey of Theory and Research, Free Press, 1974, p. 259.

[15] Treviño, L. K., Ethical decision making in organizations: A person-situation interactionist model, Academy of Management Review, Vol. 11, pp. 601-617, 1986.

[16] Knowles R. N., Self-Organising Leadership: Transparency and Trust, in Jonker J., de Witte M. (Eds.), Management Models for Corporate Social Responsibility, Springer Berlin · Heidelberg, pp. 134-139, 2006, p. 134.

[17] Pastin, M., The Hard Problems of Management: Gaining the Ethics Edge, San Francisco, California: Jossey-Bass, 1986, p. 157.

[18] Ciulla J. B., Ethics: the heart of leadership, in Maak Th., Pless N. M. (Eds.), Responsible Leadership, pp. 17-32, Routledge, 2006, p. 18.

[19] Mostovicz, E. I., and Kakabadse, N. K., Between Trust and CSR: The Role of Leadership, in Idowu, S. O., Louche, C. (Eds.) Theory and Practice of Corporate Social Responsibility, Springer-Verlag Berlin Heidelberg, pp. 159-178, 2011, p. 160.

[20] Keys T., Malnight Th. W., and van der Graaf K., Making the most of corporate social responsibility, McKinsey Quarterly, December, 2009, available at http://www.mckinsey.com/global-themes/leadership/making-the-most-of-corporatesocial-responsibility.

[21] Strand, R., CSR and leadership, in Esben Rahbek Gjerdrum Pedersen (Ed.), Corporate Social Responsibility, pp. 39-71, London, UK:SAGE, 2013.

[22] Waldman, D. A., and Siegel, D. S., Theoretical and practitioner letters: Defining the socially responsible leader, Leadership Quarterly, 19, pp. 117-131, 2008. 